\title{
Biophilic streets: a design framework for creating multiple urban benefits
}

\author{
Agata Cabanek*, Maria Elena Zingoni de Baro and Peter Newman
}

\begin{abstract}
Biophilic urbanism is bringing new perspectives to how natural systems need to be integrated into the fabric of cities. This paper shows how biophilic streets can be the front door to biophilic urbanism by integrating nature into a new street design, benefiting a range of economic, environmental and social functions. A theoretical integrated Biophilic Streets Design Framework, is outlined and evaluated through the analysis of four street revitalisation projects from Vitoria-Gasteiz, Berkeley, Portland and Melbourne. Its practical applications and multiple urban benefits will be of value to street designers globally. The Biophilic Streets Design Framework demonstrated that the four case studies meet the main design categories, which is favourable since multiple additional benefits are likely to be obtained. Future research is needed to monitor and quantify the performance of biophilic streets design to address the increasing effects of climate change, environmental degradation and biodiversity loss in a cost-effective way.
\end{abstract}

\section{Introduction}

Streets have been the focus of public life in cities since they were first built [1,2]; they provide the space and accessibility for close communal activity. The rediscovery of the social and economic value of streets since the work of Jane Jacobs [3], groups like Project for Public Spaces, and the detailed designs of Jan Gehl $[4,5]$, have enabled them to be seen as much more than spaces for mobility. This research seeks to integrate biophilic element into the design of new streets and the renewal of traditional ones to enhance the environmental component in the mix of benefits associated with streets.

Biophilic urbanism has emerged as a way to bring nature more purposefully into cities, not just between buildings and infrastructure, but into and onto them in ways that increase the connectivity between people and nature and derive benefits from natural services and functions [6-8]. Although the application of biophilic urbanism to streets has been present in the literature for some years and has informed the work of biophilic designers, it has not been formally developed into a design framework demonstrating how it can be delivered and what its multiple benefits are. This paper seeks to

\footnotetext{
* Correspondence: agata.cabanek@postgrad.curtin.edu.au

Curtin University Sustainability Policy Institute, Perth, Australia
}

address the need for a theoretically and practice informed design framework to enable more effective delivery of biophilic urbanism.

\section{Biophilia and related emerging concepts}

The emerging concepts of biophilia, biophilic design and biophilic urbanism are primarily concerned with human inclinations to affiliate with nature in urbanised environments such as cities, as suggested by Wilson [9], Kellert Heerwagen and Mador [6] and Beatley [7].

The term biophilia was first used by the German psychoanalyst Erich Fromm in 1973 and defined as 'love of life'. The American biologist E.O. Wilson advanced studies on this subject, expanding and popularising the concept of biophilia as the innate affinity of human beings with all forms of life and their inherent tendency to focus on lifelike processes in his seminal book, Biophilia (1984) [9]. Further studies demonstrated that this human inclination to affiliate with nature appears to be critical for human physical and mental health in the modern urbanised world due to humanity's origins in nature [8, 10-12]. Salingaros [12] studied this relationship in depth, also studying how humans developed their sensory space. He suggested that there are particular and very specific geometrical properties found in the

(c) The Author(s). 2020 Open Access This article is licensed under a Creative Commons Attribution 4.0 International License, which permits use, sharing, adaptation, distribution and reproduction in any medium or format, as long as you give appropriate credit to the original author(s) and the source, provide a link to the Creative Commons licence, and indicate if changes were made. The images or other third party material in this article are included in the article's Creative Commons licence, unless indicated otherwise in a credit line to the material. If material is not included in the article's Creative Commons licence and your intended use is not permitted by statutory regulation or exceeds the permitted use, you will need to obtain permission directly from the copyright holder. To view a copy of this licence, visit http://creativecommons.org/licenses/by/4.0/. 
structure of nature and in the built environment which have a positive and uplifting influence on human physical and mental conditions. These properties applied to design can therefore enhance the quality of life in urban centres. This process, called the 'biophilic effect' by Salingaros, relies on an intimate informational connection between humans and nature, and supports the need to introduce natural systems into the design of built environments [12]. Kellert [6] defined and described six biophilic design elements and seventy attributes that were later summarised for practical application in architectural and urban design. Kellert and Calabrese considered biophilic design as a means for sustainable development because it could promote care, stewardship, and attachment to place [10].

Biophilic design attempts to achieve the benefits of contact between people and nature within the modern built environment $[6,10,11]$ by integrating nature, internally and externally, into buildings, built infrastructure and across the urban space [7]. By adopting the strategies of this design principle, creating habitats for people, as biological organisms, that restore or enhance their physical and mental health, fitness and well-being becomes viable [10]. In addition to anthropocentric goals and benefits, biophilic design is a recognised solution to a spectrum of environmental challenges including urban heat island effect, particulate matter filtration and carbon dioxide sequestration, rehabilitation and restoration of lost habitats and increase of urban biodiversity. It promotes ecologically interrelated design solutions at multiple scales and enables regeneration of natural systems in the urban environment $[8,13-15]$.

Beatley (2011) extended the concept of biophilic design to the urban scale, imagining and encouraging biophilic cities. Biophilic urbanism was presented as an emerging planning and urban design approach that aimed to systematically integrate nature into the urban fabric, igniting the potential to transform barren urban spaces into places that are restorative and conducive to life $[7,13]$. Biophilic urbanism focuses on ecological systems and human activities delivered by biophilic interventions and projects. The main goal of biophilic urbanism is to improve the connection between urban dwellers and urban nature and nourish the experience of nature on a daily basis as an integral part of urban living [6-8]. In this sense, biophilic design and urbanism deliberately facilitate opportunities for urban residents to experience nature daily $[7,10]$.

The global shift towards biophilic design continues to grow. Although the terminology used varies, there are initiatives in many countries that focus on the role of nature as an essential element of everyday urban life [8]. Recent studies have shown that experiencing nature on a daily basis supports people's mental and physical health [7, 16-19]. Table 1 below outlines the multiple benefits of biophilic design to the environmental, sociopsychological and economic aspects of urban life.

Biophilic theorists Stephen Kellert and Elisabeth Calabrese [10] have formulated a range of biophilic experiences and attributes (Table 2) to facilitate the application of biophilic design theory to practice that delivers buildings and urban spaces that facilitate direct and indirect experiences of nature for urban dwellers in their daily lives. These experiences and attributes serve as principles to inform the balanced design of biophilic urban spaces. Some of these experiences are difficult to encounter in conventional streets; however, they can be incorporated into the renewal of conventional streets and the design of new ones by biophilia-literate designers.

To ensure ongoing exposure to and interaction with nature, both bond and commitment to place are needed. In order to achieve these, a design must be founded on a sound understanding of urban nature and its ecosystems as well as a sense of place. This is likely to lead to more frequent interactions between people and nature, thereby nurturing the bond between them and increasing the likelihood that residents will protect and save urban green spaces [20]. Some scholars argue that a relationship to place is needed to develop intimacy and responsibility for nature and the living world [21, 22]. Streets are an important part of any human settlement and, hence, this approach will be used to create a Biophilic Streets Design Framework presented in this paper.

\section{A brief history of streets}

Urban designers, planners and civil engineers have conceived and developed regulatory frameworks for streets to enable efficiency, security and, most of all, the rapid conveyancing of traffic, both public and private. However, the modernist tendency in the twentieth century, which saw the rise of automobile dependence, created rigid regulations that focused on efficiency and traffic control and directly contributed to the detachment of nature from urban ecologies, bioregions and climate dynamics [23]. By creating barriers in the form of dense networks of freeways and highways, the remaining urban natural areas became fragmented and isolated, along with the social neighbourhoods that they physically divided, thus disrupting their social integrity. Such impacts were built into the design frameworks created by traffic engineers.

Jane Jacobs challenged these approaches that prioritised private mobility over all other street functions and pointed to the diverse social networks characteristic of busy urban streets, which constitute the fabric of a city $[3,24]$. Those social networks are created when the structure and amenities of a street provide space for interaction and promote walkability. The abundance of social networks provide opportunity for local businesses 
Table 1 Environmental, socio-psychological and economic benefits from biophilic design based on Newman, Beatley and Boyer, 2017

\begin{tabular}{|c|c|}
\hline Area of benefit & Estimated economic and environmental benefit \\
\hline Better workplace productivity & $\begin{array}{l}\text { \$2000 per employee per year from daylighting; } \\
\$ 2990 \text { per employee over } 4 \text { months when desks angled to view nature. }\end{array}$ \\
\hline Improved health and healing & $\$ 93$ million per year in reduced hospital cost if natural features provided in the U.S. hospitals. \\
\hline Increased retail potential & $\begin{array}{l}\text { Skylighting in a chain store would result in a } 40 \% \text { sales increase, } \pm 7 \% \text {. } \\
25 \% \text { higher sales in vegetated street frontage. }\end{array}$ \\
\hline Decreased crime and violence & $\begin{array}{l}\text { Public housing with greenery had } 52 \% \text { reduction in felonies. } \\
\text { Biophilic landscapes introduced across New York City would save } \$ 1.7 \text { billion through crime } \\
\text { reduction. }\end{array}$ \\
\hline Increased property values & $\begin{array}{l}\text { Biophilic buildings attract higher rental prices, 3\% per square foot or } 7 \% \text { in effective rents, selling at } \\
\text { prices } 16 \% \text { higher. }\end{array}$ \\
\hline Employee attraction & Biophilics attract and retain high-quality workers. \\
\hline Increased liveability in dense areas & Green features increase salability of densely built apartment blocks. \\
\hline Carbon sequestration & $\begin{array}{l}\text { In Singapore aboveground vegetation sequesters } 7.8 \% \text { of the total emitted daily carbon dioxide } \\
\text { (Velasco et al., 2016). }\end{array}$ \\
\hline $\begin{array}{l}\text { Reduced urban heat island effect and reduced } \\
\text { energy consumption }\end{array}$ & $\begin{array}{l}\text { Due to shading provided by urban trees, in Los Angeles annual residential air-conditioning (A/C) bills } \\
\text { can be reduced directly by about US\$100 million, additional savings of US\$70 million in indirect cool- } \\
\text { ing, US\$360 million in smog-reduction benefits (Rosenfeld et al., 1998). }\end{array}$ \\
\hline Water management and quality & Up to $70 \%$ of stormwater retention capability, depending of the local climate and other conditions. \\
\hline Air quality & $\begin{array}{l}\text { Urban street canyons full of greenery can reduce particulate matter by up to } 60 \% \text { and nitrogen } \\
\text { dioxide by up to } 40 \% \text {. }\end{array}$ \\
\hline Biodiversity conservation & $\begin{array}{l}\text { A study of } 115 \text { wildly colonized green roofs in north of France found that } 86 \% \text { of species were } \\
\text { native to the area. }\end{array}$ \\
\hline
\end{tabular}

to thrive; hence, Jacobs was able to construct a theoretical approach to show why streets were essential to a city's economy $[25,26]$. This has since developed into a strong plea for dense urbanism and street fabric to be seen as essential components of how cities create wealth and opportunity [27-30].

Urban designers, such as Jan Gehl, criticised modernist planning ideologies and how they dismissed the value of historic streets by allowing cars to invade every available space in cities $[4,31]$. Through a series of reports on cities around the world, Gehl created a new framework for how streets should be designed to facilitate close interactions between people that enable multiple economic and social benefits and reduce the environmental impact of cars [31, 32]. Gehl's framework for urban planners, landscape architects and architects reinforces walkability, active street frontages and street furniture as integral parts of city policy [31], to ensure streets are welcoming spaces in the pattern of daily activities. Table 3 below shows Gehl's 12 quality criteria as a framework for this approach to street design, with an additional column that shows how biophilic design interventions can enrich the pedestrian landscape and experience.

Cities are changing from sprawl and car dependency to transit and more compact urban forms, and so are their streets. The focus of urban streets is changing from ensuring traffic movement efficiency to a more peoplecentred design that puts pedestrians first, then cyclists and transit, and lastly private motorised vehicles [33, 34]. Building on Gehl's work and collaborations among experts from global cities, the National Association of City Transportation Officers (NACTO) created the Global Street Design Guide [35], which is intended to be a baseline for urban street design. The Guide aims to

Table 2 Experiences and attributes of biophilic design. Source: Kellert and Calabrese (2015)

\begin{tabular}{|c|c|c|}
\hline Direct experience of nature & Indirect experience of nature & Experience of space and place \\
\hline $\begin{array}{l}\text { - Light } \\
\text { - Air } \\
\text { - Water } \\
\text { - Plants } \\
\text { - Animals } \\
\text { - Weather } \\
\text { - Natural Landscapes and Ecosystems } \\
\text { - Fire }\end{array}$ & $\begin{array}{l}\text { - Images of Nature } \\
\text { - Natural Colours } \\
\text { - Stimulating Natural Light and Air } \\
\text { - Naturalistic Shapes and Forms } \\
\text { - Evoking Nature } \\
\text { - Information Richness } \\
\text { - Age, Change, and the Patina of Time } \\
\text { - Natural Geometries } \\
\text { - Biomimicry }\end{array}$ & $\begin{array}{l}\text { - Prospect and Refuge } \\
\text { - Organized Complexity } \\
\text { - Integration of Parts to Wholes } \\
\text { - Transitional Spaces } \\
\text { - Mobility and Wayfinding } \\
\text { - Cultural and Ecological Attachment to Place }\end{array}$ \\
\hline
\end{tabular}


Table 3 Gehl's 12 quality criteria concerning the pedestrian landscape along with added biophilic design interventions

\begin{tabular}{|c|c|c|c|c|}
\hline \multicolumn{4}{|l|}{12 quality $\mathrm{cr}$} & \multirow[b]{2}{*}{$\begin{array}{l}\text { Biophilic design interventions } \\
\text { Vegetated hedges as protection from traffic. } \\
\text { Tree canopy to mitigate weather conditions and } \\
\text { reduce noise } \\
\text { Plant palette designed to capture and retain airborne } \\
\text { particulate matter } \\
\text { Dynamic \& diffuse lighting provided by tree and } \\
\text { shrub planting, and water features; } \\
\text { Mobile structures such as 'CityTree' and Mobile Forest, } \\
\text { Pop-up parklets }\end{array}$} \\
\hline Protection & $\begin{array}{l}\text { Protection against } \\
\text { traffic and accidents } \\
- \text { feeling safe } \\
\text { Protection for } \\
\text { Pedestrians and } \\
\text { cyclists. } \\
\text { Eliminating fear of } \\
\text { traffic. }\end{array}$ & $\begin{array}{l}\text { Protection against } \\
\text { Crime \& violence } \\
\text { - feeling secure } \\
\text { Lively public realm. } \\
\text { Eyes on the street. } \\
\text { Overlapping functions } \\
\text { day and night. } \\
\text { Good lighting. }\end{array}$ & $\begin{array}{l}\text { Protection against } \\
\text { Unpleasant sensory } \\
\text { Experiences } \\
\text { Wind. } \\
\text { Rain/snow. } \\
\text { Cold/heat. } \\
\text { Pollution. } \\
\text { Dust, noise, glare. }\end{array}$ & \\
\hline \multirow[t]{2}{*}{ Comfort } & $\begin{array}{l}\text { Opportunities to walk } \\
\text { Room for walking. } \\
\text { No obstacles. } \\
\text { Good surfaces. } \\
\text { Accessibility for } \\
\text { everyone. } \\
\text { Interesting facades. }\end{array}$ & $\begin{array}{l}\text { Opprtunities to stand/stay } \\
\text { Edge effect/attractive } \\
\text { zones for standing/ } \\
\text { staying. } \\
\text { Support for standing. }\end{array}$ & $\begin{array}{l}\text { Opportunities to sit } \\
\text { Zones for sitting. } \\
\text { Utilising advantages: view, } \\
\text { sun, people. } \\
\text { Good places to sit. } \\
\text { Benches for resting. }\end{array}$ & \multirow{2}{*}{$\begin{array}{l}\text { Tree canopies } \\
\text { Vegetated walk paths. } \\
\text { Vertical gardens (creepers or green walls). } \\
\text { Natural materials. Naturalistic shapes and forms } \\
\text { (facades and pavements). } \\
\text { Urban furniture integrated with plant beds, vertical } \\
\text { gardens, water features. } \\
\text { Creating interesting views with greeneries. } \\
\text { Using vegetated hedges to create noise buffers/ } \\
\text { intimate spaces/exercise and play spaces. } \\
\text { Biophilic structures such as parklets, 'CityTree', Green } \\
\text { bus stop shelters }\end{array}$} \\
\hline & $\begin{array}{l}\text { Opportunities to see } \\
\text { Reasonable viewing } \\
\text { distances. } \\
\text { Unhindered sightlines. } \\
\text { Interesting views. } \\
\text { Lighting (when dark). }\end{array}$ & $\begin{array}{l}\text { Opportunities to talk and } \\
\text { listen } \\
\text { Low noise level. } \\
\text { Street furniture that } \\
\text { provides 'talkscapes'. }\end{array}$ & $\begin{array}{l}\text { Opportunities for play and } \\
\text { exercise } \\
\text { Invitations for creativity, } \\
\text { physical activity, exercise } \\
\text { and play. } \\
\text { By day and night. } \\
\text { In summer and winter. }\end{array}$ & \\
\hline Delight & $\begin{array}{l}\text { Scale } \\
\text { Building and spaces } \\
\text { designed to human } \\
\text { scale. }\end{array}$ & $\begin{array}{l}\text { Opportunities to enjoy } \\
\text { the positive aspects of } \\
\text { climate } \\
\text { Sun/shade } \\
\text { Heat/coolness } \\
\text { Breeze }\end{array}$ & $\begin{array}{l}\text { Positive sensory experiences } \\
\text { Good design and detailing. } \\
\text { Good materials. } \\
\text { Fine views. } \\
\text { Trees, plants, water. }\end{array}$ & $\begin{array}{l}\text { Well-designed public green spaces to fit different age } \\
\text { groups needs and expectations. } \\
\text { Plant selection according to climate, soil, seasons to } \\
\text { maximise sensory and aesthetic experiences. } \\
\text { Use greeneries to (re) create human scale. } \\
\text { Public art } \\
\text { Mobile and temporary structures such as parklets, } \\
\text { pop-up gardens, 'CityTree', Mobile Forest, Green bus } \\
\text { shelters }\end{array}$ \\
\hline
\end{tabular}

better balance the needs of street users (with more emphasis on the needs of pedestrians) and supports the creation of quality spaces based on the consideration of people and place.

Finally, the concept of biophilic design contributes to the creation of urban streets with attractive, healthy, liveable and restorative environments and nature experiences at the door step for both dwellers and other street users within gradually densifying urban precincts through urban infill.

\section{Developing a framework for biophilic streets design}

An urban street can be compared to an evolving organism adapting and responding to its environment. Although cities contain a broad range of street typologies, depending on the context, they generally provide space for transportation, commuting, physical activities and social and economic life at different scales [36]. Traffic engineers and urban designers often fail to plan streets that deliver positive social or health-related outcomes. Reconceiving urban streets as places, rather than just movement spaces, would facilitate the provision of these positive outcomes. Furthermore, as the time people spend in streets compared to the time they spend in parks is eight to ten times more [37], the design of streets-to support health and well-being - should be considered before parks [36, 38].

Streets provide diverse experiences to their users, including the experience of nature. Identifying the most appropriate design strategies to apply to any given street would need to take into account a range of circumstances and requirements particular to that location. This may include the history of the street, the existing social, environmental, architectural and structural conditions, existing infrastructure, policies and regulations, project size, zoning and land use and its potential future as a place.

Based on the experiences of biophilic places (Table 2) and their many benefits, a list of the characteristics of a biophilic street were compiled as an analytical framework of six categories. These categories consider design functions, design objectives, design elements and the characteristics of a biophilic street. The six categoriestraffic planning, energy management, stormwater management, biodiversity management, street furniture and activities and education-are derived from the intended purposes for which streets are designed, and chosen 
because of their potential to be improved by the addition of biophilic elements. Elements that have been successfully designed, developed and applied in real-life projects form the base for a biophilic street. The proposed Framework is set out in Table 4 below, followed by an explanation of each category. It is then applied to four examples of a street revitalisation project to illustrate its usefulness.

\section{Mobility planning}

A street often serves as a front yard for residents; it must, therefore, provide a safe place to move around, whether by car, bicycle, transit or on foot. However, used only for transportation, a street loses its relevant social and economic functions, such as providing a safe space for interaction, as identified by Jacobs $[3,26]$ and Gehl [5]. In the wake of the urban renewal movement, many cities are restoring or redesigning their main streets and boulevards to serve as linear parks and other types of hospitable public places promoting social interaction and walking. As a result, the most successful transformations add value to adjacent properties and local businesses [39]. The Biophilic Streets Framework takes these fundamental characteristics of streets and seeks to show that there are biophilic design principles and strategies that could help streets perform these functions more effectively.

To achieve safety standards on biophilic streets, traffic calming schemes should apply, including techniques designed to lessen the impact of traffic. Trees and bushes are well known to do this by psychologically giving drivers a sense of needing to go slower [40]. The location of measures and devices (including types of vegetation) determines the effectiveness of traffic calming

Table 4 Framework for biophilic streets design

\begin{tabular}{|c|c|c|c|c|}
\hline \multicolumn{2}{|c|}{ Framework functions and objectives } & \multicolumn{3}{|l|}{ Biophilic design elements } \\
\hline $\begin{array}{l}\text { Design } \\
\text { functions }\end{array}$ & Selected design objectives & Building façades & Road reserves & Pocket parks \\
\hline $\begin{array}{l}\text { Traffic } \\
\text { planning }\end{array}$ & $\begin{array}{l}\text { Creating space for biophilic } \\
\text { designs by redesigning traffic } \\
\text { lanes, traffic calming schemes, } \\
\text { reducing lanes, prioritizing } \\
\text { pedestrians, transit and bicycle } \\
\text { lanes and providing pocket parks. }\end{array}$ & $\begin{array}{l}\text { Integrating vertical } \\
\text { greenery into and onto } \\
\text { buildings, such as green } \\
\text { walls, green balconies, } \\
\text { planter boxes; green roofs. }\end{array}$ & $\begin{array}{l}\text { Integrating native gardens, edible } \\
\text { gardens, nature playgrounds and } \\
\text { other biophilic features on } \\
\text { verges, median strips, round- } \\
\text { about, 'ramblas', green bridges } \\
\text { and flyovers, buffers between } \\
\text { roads and cycling and/or pedes- } \\
\text { trian paths. }\end{array}$ & $\begin{array}{l}\text { Integrating native gardens, edible } \\
\text { gardens, nature playgrounds, } \\
\text { water features, habitats for birds, } \\
\text { insects and small animals, street } \\
\text { furniture and amenities in } \\
\text { median strips, 'ramblas', } \\
\text { roundabouts, vacant lots, plazas, } \\
\text { spaces between buildings. }\end{array}$ \\
\hline $\begin{array}{l}\text { Energy } \\
\text { management }\end{array}$ & $\begin{array}{l}\text { Cooling streets for walking, } \\
\text { reducing urban heat island effect } \\
\text { and saving energy through } \\
\text { insulating buildings. }\end{array}$ & $\begin{array}{l}\text { Green walls, roofs, and } \\
\text { balconies to provide } \\
\text { thermal insulation; cooling } \\
\text { (evapotranspiration); air } \\
\text { purification; relaxation. } \\
\text { Combination of green } \\
\text { roofs and solar panels. }\end{array}$ & $\begin{array}{l}\text { Tree canopies that shade } \\
\text { pedestrians as well as shading } \\
\text { buildings. }\end{array}$ & $\begin{array}{l}\text { Pocket parks can be built around } \\
\text { all three energy management } \\
\text { ideas. }\end{array}$ \\
\hline $\begin{array}{l}\text { Stormwater } \\
\text { management }\end{array}$ & $\begin{array}{l}\text { Water retention, purification, and } \\
\text { reuse. }\end{array}$ & $\begin{array}{l}\text { Green walls, green roofs, } \\
\text { green balconies that filter } \\
\text { rain. }\end{array}$ & $\begin{array}{l}\text { Street trees, tree pits, linear } \\
\text { gardens, bioswales, rain gardens, } \\
\text { daylighted streams. }\end{array}$ & $\begin{array}{l}\text { Rainwater tanks, pervious } \\
\text { pavements. }\end{array}$ \\
\hline $\begin{array}{l}\text { Biodiversity } \\
\text { management }\end{array}$ & $\begin{array}{l}\text { Biodiversity enhancement, } \\
\text { restoration, creation of various } \\
\text { habitat sizes and types that } \\
\text { enable regeneration of urban } \\
\text { ecosystems. }\end{array}$ & $\begin{array}{l}\text { Green walls, green roofs, } \\
\text { green balconies. }\end{array}$ & $\begin{array}{l}\text { Street trees, tree pits, linear } \\
\text { gardens, bioswales, rain gardens, } \\
\text { daylighting streams. }\end{array}$ & $\begin{array}{l}\text { Plant beds, potted shrubs and } \\
\text { trees, green walls, water features. }\end{array}$ \\
\hline $\begin{array}{l}\text { Street } \\
\text { furniture }\end{array}$ & $\begin{array}{l}\text { Incorporating biophilics into } \\
\text { every small function in the street, } \\
\text { including seats, signs, bus } \\
\text { shelters, street art. }\end{array}$ & $\begin{array}{l}\text { Street art combined with } \\
\text { filtration systems to } \\
\text { conduct runoff from green } \\
\text { roofs. }\end{array}$ & $\begin{array}{l}\text { Parklets } \\
\text { Green roofs on top of bus and } \\
\text { transit shelters. } \\
\text { Street art combined with } \\
\text { filtration systems. } \\
\text { 'City trees' installation to facilitate } \\
\text { air purification. } \\
\text { Vertical pallet edible gardens. }\end{array}$ & $\begin{array}{l}\text { Urban furniture to support } \\
\text { natural systems. } \\
\text { Green roofs on top of bus and } \\
\text { transit shelters. } \\
\text { Street art combined with } \\
\text { filtration systems. } \\
\text { 'City trees' installation to facilitate } \\
\text { air purification. } \\
\text { Vertical pallet edible gardens. }\end{array}$ \\
\hline $\begin{array}{l}\text { Activity and } \\
\text { education }\end{array}$ & $\begin{array}{l}\text { Enabling both activity that uses } \\
\text { street functions and } \\
\text { understanding of how nature fits } \\
\text { into the city as well as the social } \\
\text { and cultural value of the street. }\end{array}$ & $\begin{array}{l}\text { Tourist and visitor } \\
\text { information in streets } \\
\text { explaining biophilic } \\
\text { facades. }\end{array}$ & $\begin{array}{l}\text { Integrated street furniture with } \\
\text { green features explained. } \\
\text { Educational features - } \\
\text { information plates, educational } \\
\text { stations; activity points (smart } \\
\text { play equipment, art installations, } \\
\text { water features). }\end{array}$ & $\begin{array}{l}\text { Integrated street furniture with } \\
\text { green features explained. } \\
\text { Educational features - } \\
\text { information plates, educational } \\
\text { stations; activity points (smart } \\
\text { play equipment, art installations, } \\
\text { water features). }\end{array}$ \\
\hline
\end{tabular}


schemes, and those again depend on the type of streets they are introduced on: a residential road, a road with traffic functions or a transit road having a combination of speeds that enable rapid mobility (between stations) and slow mobility (within station precincts). These are within the purview of traffic engineering and planning, where concepts of place and movement and melding.

An example of traffic calming structures featuring engineered stormwater gardens are chicanes [41, 42]. These structures slow traffic by confining the travel lanes. They also feature depressed interiors capturing stormwater which feed garden beds, shrubs and trees creating biophilic systems. Chicanes can be formed using sculpture, plantings or parking to enhance the appearance and function of a street. They are best used on narrow roads, to prevent cars from swinging out to maintain their speed around the bends; narrow, curving roads encourage motorists to drive more slowly and carefully [43].

\section{Energy management}

Energy management in urban streets serves multiple functions: helping to cool a city where urban heat island effect is leading to ill health; making walkability easier and hence improving urban economics in the area; and helping to cool the buildings next to the street. In multiple studies, urban greenery has shown cooling capabilities [44-46]. Parks lower the air temperature within their territory, but the impact on the adjacent built environment is limited [47]. Urban tree canopy provides a cooling effect in street canyons [48, 49]; some studies show air temperature under a canopy are reduced by 0.7-1.3 degrees Celsius in the early afternoon [50]. The cooling capacity of a tree canopy depends on its characteristics, as well as the characteristics of the street such as surface materials, geometry, building height and how densely the street is built up. However, at night time the air temperature under the canopy, where the radiating heat is captured, can be 0.5 degrees Celsius higher than in an open space reference point [46].

Biophilic structures installed directly onto buildings include green walls and roofs. By introducing such structures, the air temperature in street canyons can be reduced as well as the demand for cooling and heating of buildings. A multi-case study by Alexandri and Jones [51] was conducted in nine cities to assess the thermal effect of green walls and roofs in urban canyons across different microclimates. The authors concluded that the solar radiation absorbed by the roof and facade surface was reduced by applying greenery, and that the heat fluxes vary on different vegetated surfaces and in different microclimates. The outdoor air temperature and energy savings were measured in nine cities. In Hong Kong the analysis of canyon air temperature showed a decrease by a maximum of 3.9 degrees Celsius, while in hot and arid Riyadh the maximum flux was 18.7 degrees Celsius on the green wall surface. Roof surface temperatures are even more significant. In Mumbai the temperature decreased by 26.1 degrees Celsius and in London the maximum decrease was 19.3 degrees when comparing unvegetated and vegetated rooftops.

\section{Stormwater management}

Cities feature vast amounts of impervious surfaces producing significant run-off that needs to be managed. Green infrastructure has been found to retain most of the polluted initial run-off through bio-retention and bio-filtration. Through these two processes, rain water can be permanently retained or temporarily detained. Captured stormwater contributes to groundwater recharge and helps sustain the whole water cycle [36]. Biophilic urbanism not only picks up all these design features, it adds more.

In recent years, biophilic designers have transformed one of the largest impervious areas-roof tops-into intensive and extensive gardens and meadows [52, 53], creating efficient stormwater management systems [54]. Stovin [55] tested green-roof stormwater retention on a small-scale trial and found that the retention capacity was on average 34 , and $57 \%$ of peak flow run-off.

In another study led by Kew [53], rainfall was shown to have little or no impact on the green wall. Most of the rainfall was blocked by the gutters integrated into the system. In order to improve the efficiency of the green roof and wall systems, the run-off from the roof was collected into cisterns and then used to irrigate the green walls with drip irrigation. Green walls do not directly collect significant amounts of precipitation; however, they are often used to control first stormwater flush. The efficiency of a particular system does not only depend on technological advancement, but also on climatic conditions and the vegetation and growing medium as well as whether the green wall is facing the main weather fronts [56].

Thus, a green roof can be considered an alternative to a conventional stormwater management system and become integrated into the concept of a biophilic street. In an urban setting, a total facade area usually exceeds a roof area; thus, a well-designed green wall could become part of the green-roof stormwater system if that is a desired outcome. With more competition for ground vertical surfaces in urbanised areas, the potential of rooftops and vertical surfaces for stormwater management is significant. The success of green roof and green wall stormwater management can be measured by the increasing number of municipalities, developers, and individuals undertaking this first flush control [53]. A biophilic 
street can thus become part of a whole new stormwater management system.

\section{Biodiversity management}

Efforts to preserve global biodiversity are frequently centred on saving large remaining natural habitats [57]. However, several studies on urban greenery provide data on biodiversity in parks, gardens, squares, streets and other places where flora and fauna can be found. Urban parks offer refuge to native biota [58] and urban streets also have the ability to support biodiversity [58, 59] by providing food, shelter and breeding sites and facilitating the movement of wildlife.

Significant percentages of animal and plant species, including endangered species, inhabit urban forests. For example, highly urbanised environments have been found to accommodate $20 \%$ of the world's avian biodiversity [60]. A study by Threfall [59] showed a strong connection between understorey vegetation and native bird species in Melbourne, Australia.

Innovative structures like green walls and roofs are popular sustainable design interventions due to their ability to cool the building envelope and create aesthetically pleasing facades. However, the structure of a biophilic street with large variations in the height of different vegetation types on various buildings and in the street itself, should support biodiversity in cities at a landscape scale. The design detail of a biophilic street could be used to enable a range of biodiversity goals, for example, by acting as a corridor to facilitate movement [61]. At a local scale, vertical greening systems can be used as means to improve the environmental conditions, with even simple flora assemblages providing habitat for invertebrates [62] as well as nesting, food and shelter resources for urban ornithology $[62,63]$. The size of impact on biodiversity from such biophilic street structures is yet to be ascertained, though undoubtedly the plant species introduced will influence the richness of animal species. Whether this could support urban ecological restoration has not been researched at a significant scale [64].

In a study undertaken in Staffordshire, United Kingdom, a number of bird species of conservation concern were reported exploiting and nesting in some newly created green walls and their immediate surroundings [65]. The researchers concluded that encouraging homeowners and businesses to install green walls could be an effective way of providing habitat and resources for birds in an urban environment. This also highlights an important opportunity for urban open space designers and managers to make a positive impact on biodiversity through relatively small and cost-effective improvements in vegetation quality by creating more biophilic streets.

In a study of bio-retention swales undertaken in Australia, researchers observed that the swales presented greater richness and diversity of species than gardens and lawn-type green spaces. Bio-retention swales are vegetated water sensitive urban design (WSUD) structures built to support more sustainable urban infrastructure [66]. This system is increasing in popularity and replacing customarily vegetated areas of streetscapes with sustainable natural assets [67]. It is likely to become a more mainstream design outcome, however, if part of a biophilic street.

\section{Street furniture}

The design innovations outlined above comprise building biophilic elements along street spaces and on facades of buildings for a range of reasons. This section focuses on the potential of street furniture, an important element of every street, to fulfil a biophilic function in addition to its usual function.

Urban street furniture is designed and integrated into streets for a range of reasons but rarely for purposes related to biophilic urbanism. This is possible to achieve and likely to work best if its biophilic potential is incorporated into a design from the beginning rather than added after other elements have been considered or are in place. Bus shelters, bicycle stands, street art, play installations and benches have been used in several major cities to support native flora and fauna, facilitate habitation for wildlife and provide various other ecosystem services. So it is possible to add this dimension to a biophilic street.

Maynard Green Street in Seattle, United States, is an example of harnessing urban street furniture to support natural systems. The street was refurbished in 2010 as part of Seattle's Green Street program, which was established to enhance open space and pedestrian circulation. Combining public art with a water filtration system, the Maynard project incorporates rooftop run-off that enters a cistern before flowing down the custom-designed planters. The planters also function as benches for pedestrians ascending and descending the steep street [68].

Another example of innovative street furniture is the CityTree designed by a German start-up, Green City Solutions $[69,70]$. Their key aim was to build a street furniture element able to provide air-purifying solutions in a man-made ecosystem. The structure consists of biologically engineered moss and vascular plant species grown using a green wall system. Rainwater is gathered and recycled through the system while irrigating the plants. The efficiency of this street furniture still needs to be tested and proven in multiple locations. However, the company claims that a single CityTree is capable of combating air pollutants as effectively as 275 urban trees at $5 \%$ of the cost and requiring $99 \%$ less space. They also claim that a single CityTree has the ability to reduce air pollution by $30 \%$ within a $164-\mathrm{ft}$ radius. So far, the 
CityTree has been tested in several large cities across the globe: Berlin, Paris, Glasgow, Oslo and Brussels [69].

Bus shelters have been included in greening projects in many cities. Green shelter prototypes have been created to provide more inviting and enjoyable experiences while addressing the needs of transit waiting areas. Trials have highlighted the benefits of integrating biophilic design and sustainable transit to lessen the environmental impact of climate change.

The Living Bus Shelter in Minneapolis, United States, was an initiative between the Minneapolis Downtown Improvement District and Metro Transit. The structure was comprised of vertical pallet gardens containing a variety of edible plants. After the installation, commuters were encouraged to explore the plants by touching, smelling, tasting or even taking them home. The data, which emerged in a survey, showed improved transit user experience. All respondents gave positive answers when asked whether they favoured the incorporation of greenery into the shelter. The aesthetic character of the installation was rated nine out of ten and users generally expressed enthusiasm about the greenery and suggested increasing the volume. In the end, $65 \%$ of respondents gave the green light to the local authorities to continue reimagining transit shelters through green installations [71].

Other cities, such as San Francisco and Philadelphia in the United States, Sheffield in the United Kingdom, and Eindhoven in Germany, introduced similar programs of greening their transit shelters. The local authorities intended to provide an attractive green space in the unconventional location of concrete dominated urban space. Vegetated roof installations on a bus shelter in Philadelphia aimed to raise awareness about urban stormwater management [72]. In Eindhoven, bus shelter design aspired to perfect integration with the existing city fabric. The green bus stop design was selected through a competition organised by the council [73]. Vegetation installed on public transport shelters is considered to be in a prime position to filter contamination and particulate matter from transport vehicles [35]. These initial attempts to green bus shelters successfully captured the imaginations of city inhabitants while promoting sustainable and feasible innovations.

\section{Activity and education}

Gehl Architects identify three types of activities that occur in urban environments: necessary, optional and social activities. Optional activities depend on the quality of a place; the more attractive a place is, the more often pedestrians choose to stroll, play, sit and eat there. The design features of biophilic streets should encourage these optional activities, facilitate community and reinforce the identity of a neighbourhood. The best executed biophilic streets will therefore be full of nature, bringing more people outside and into shared activities. An intense mixture of uses also makes streets safer [5].

When streets function well on an everyday level of biophilic experience, they provide opportunities for activities like teaching, learning and entertainment. Wider streets, like boulevards, provide opportunities for entertainment such as play equipment, art installations, water fountains, games and other foci for social interactions. A good example is found in Montreal, Canada, where a lifeless median of Promenade des Artistes has been transformed into an active space as part of a biophilic street regeneration. Twenty-one multi-coloured, musical swings were installed in order to foster play and social interaction between pedestrians of all ages and backgrounds [74].

Environmental agencies and local councils encourage communities to engage in the renewal and enhancement of urban nature. In 2015, The Environmental Protection Authority (EPA) in South Australia launched the Rain Garden 500 program [75], through which local councils and community groups can apply for funding to build rain gardens. The program helps to improve the quality of stormwater run-off. Another purpose is to educate communities and school children about the impact residents may have on the quality of urban waterways. Information plaques were installed to spread knowledge about the importance of water harvesting projects. Thus, design elements that enable activities and education in a biophilic street are part of the Framework presented in this paper.

The five characteristics of a street that lend themselves to the application of biophilic design elements, as outlined above and in Table 4, will now be discussed in relation to four examples of a street revitalisation project to determine how effectively the proposed Biophilic Streets Design Framework can contribute to creating more biophilic cities with multiple urban benefits.

\section{Potential issues and trade-offs}

Potential benefits of the biophilic streets have been presented; however, it is also necessary to address potential issues and trade-offs associated with the proposed concept. Some issues may include a high initial cost of construction, high cost of maintenance and limited onstreet parking due to the expansion of green infrastructure within street medians. A higher concentration of plants (native or edible) or rain gardens may produce higher amounts of organic litter, which may become a nuisance to some pedestrians. However, the changing seasons and patina of time-the two biophilic experiences-are achieved, enriching and improving the overall biophilic experience.

Green infrastructure within street medians may generate higher maintenance costs. For example, the 
maintenance of green walls and roofs extend the area of greenery expected in conventional streets, which may result in additional costs.

The maintenance costs could be shared between the local authority and the residents (private and commercial) of a biophilic street. A successful maintenance sharing program can be found in Portland, Oregon. The Green Street Stewards were volunteers who were responsible for occasional removal of sediments, collection of organic matter and rubbish from the planters and watering [76]. By facilitating the stewardship program, the city helped to create bonds between the residents and the local urban nature, at the same time reducing the cost of maintaining the streets.

Research into costs and benefits of selected street elements, such as trees, can be found in the scientific literature [77, 78]; however, a biophilic street-as a green infrastructure project-would require a holistic economic analysis to prove the feasibility of a proposed design scheme.

\section{Analysis of the selected streets}

Four illustrative examples of a street revitalisation project were selected for analysis through the lens of the proposed Biophilic Streets Framework: a former urban highway in Vitoria-Gasteiz, Spain; the streets renewal project in Downtown Berkeley and SW Montgomery Green Street in Portland, United States; and the Green your Lane project in Melbourne, Australia. The selected streets serve as examples of a diverse approach to street design using multiple tools and strategies to achieve high performing biophilic public spaces. They represent different types of biophilic streets in terms of their hierarchy and their functions. Their biophilic street features are summarised in Table 5 using each of the Framework's six design characteristics.

\section{Gasteiz Hiribidea in Vitoria-Gasteiz, Spain}

Vitoria-Gasteiz, the capital city of the Basque Country, has been committed to the principles of sustainable urban development for many years. In 2013, VitoriaGasteiz joined the league of biophilic cities with a showcase of successful projects and interventions fulfilling the biophilic urbanism agenda $[7,8]$. The urban greenery of Vitoria-Gasteiz features 50,000 plants composed of 381 species of trees and shrubs, including tree-lined streets and avenues connecting urban biodiversity [79]. One of the main roads, Gasteiz Hiribidea, underwent a major revitalisation and became an example of good practice for other cities to follow. In the past, the street was an eight-lane highway, but after a major redesign, it now features a naturalised stream and an abundance of greenery including trees, a grassed tram line, two cycle tracks and broad sidewalks. The naturalised stream, which was once channelled under the streets, now runs along the pavement. It features native aquatic and riparian vegetation bordered by a reinforced embankment. The stream provides habitat to small animals for feeding, breeding and shelter, enhancing local urban biodiversity (Fig. 1). Together with the large green envelope of the Palace of Europe, the stream creates a biodiversity hotspot in the city centre providing habitat to over 70 species of butterflies [7]. Flowering perennials and annuals create a vertical botanical garden which also serves as an educational centre bringing local nature closer to city dwellers. The street, which once had no room for nature, now abounds with it and its natural processes are available to observe and interact with it on a daily basis. This revitalisation project reinforces the cultural value of the place while also promoting environmental awareness by building a relationship between citizens and nature.

So far, the City of Vitoria-Gasteiz has developed a plan for improving bio-capacity, biodiversity and urban landscape. The most important project is the creation of an external and internal green belt and the activation of the potential of urban green spaces connected by a network of green and biophilic streets, avenues, wooded garden walks and urban trails. The connection between innovative biophilic structures and traditional greenery secures the effectiveness of the urban green network to perform ecological functions and increase biodiversity in the city. The biophilic street in Vitoria-Gasteiz is emerging as a major part of the city's biophilic urbanism.

\section{Downtown Berkeley, United States}

The aim of the streets renewal project in Downtown Berkeley was to provide the usual functions of a street, but to add ecological features in an innovative way on a limited budget. In 2012, the City of Berkeley issued The Street \& Open Space Improvement Plan (SOSIP) to present a shared vision for the future of Downtown Berkeley's public realm (Fig. 2) [80]. The revitalisation project included Shattuck Avenue and Park Blocks, Shattuck Square, University Avenue, Centre Street Plaza, Greenway, Hearst Street and Ohlone Greenway. A number of sustainability goals were established featuring biophilic attributes and experiences. The main objectives of the major projects were walkability, place-making, public life, sustainability, health and comfort. To achieve these a community engagement process was undertaken [6].

The strategies employed in the Downtown project were to create a more vibrant, attractive and memorable destination. The information gathered during community consultations informed the focus of the project: public life and the provision of space for a myriad of activities-social, cultural and business-engaging all residents and visitors. The leading 
Table 5 Application of the framework for biophilic streets design in four analysed street projects

\begin{tabular}{|c|c|c|c|c|}
\hline \multirow{2}{*}{$\begin{array}{l}\text { Functions of } \\
\text { a biophilic } \\
\text { street }\end{array}$} & \multicolumn{4}{|c|}{ Biophilic design elements applied to analysed street projects } \\
\hline & $\begin{array}{l}\text { Gasteiz Hiribidea, Vitoria-Gasteiz, } \\
\text { Basque Country, Spain }\end{array}$ & $\begin{array}{l}\text { Downtown in Berkeley, California, } \\
\text { USA }\end{array}$ & $\begin{array}{l}\text { SW Montgomery Street, } \\
\text { Portland, Oregon, USA }\end{array}$ & $\begin{array}{l}\text { Green Lanes, Melbourne, Victoria, } \\
\text { Australia }\end{array}$ \\
\hline $\begin{array}{l}\text { Traffic } \\
\text { planning }\end{array}$ & $\begin{array}{l}\text { - prioritizing pedestrians and } \\
\text { cyclists; } \\
\text { - enhancing facilities for transit; } \\
\text { - slowing traffic. }\end{array}$ & $\begin{array}{l}\text { - prioritizing pedestrians and } \\
\text { cyclists; } \\
\text { - enhancing walkability standards; } \\
\text { - reducing existing traffic lanes; } \\
\text { - lowered traffic speed. }\end{array}$ & $\begin{array}{l}\text { - prioritizing pedestrians } \\
\text { and cyclist (kerb-less } \\
\text { paving); } \\
\text { - narrowing existing } \\
\text { traffic lanes; } \\
\text { - lowered traffic speed; } \\
\text { - sections of the street } \\
\text { closed to traffic. }\end{array}$ & $\begin{array}{l}\text { - limited traffic (local only) } \\
\text { - shared space between } \\
\text { pedestrian and vehicles. }\end{array}$ \\
\hline $\begin{array}{l}\text { Energy } \\
\text { management }\end{array}$ & $\begin{array}{l}\text { - energy reduction due to } \\
\text { ecological runoff treatment; } \\
\text { - insulation capabilities of green } \\
\text { walls and roofs systems; } \\
\text { - heat island effect mitigation by } \\
\text { tree canopies, landscaping and } \\
\text { waterbodies. }\end{array}$ & $\begin{array}{l}\text { - energy reduction due to } \\
\text { ecological runoff treatment; } \\
\text { - insulation capabilities of green } \\
\text { walls and roofs systems; } \\
\text { - heat island effect mitigation by } \\
\text { tree canopies, landscaping and } \\
\text { waterbodies. }\end{array}$ & $\begin{array}{l}\text { - energy reduction due } \\
\text { to ecological runoff } \\
\text { treatment; } \\
\text { - insulation capabilities } \\
\text { of green walls and } \\
\text { roofs systems; } \\
\text { - air temperature } \\
\text { regulation through } \\
\text { landscaping. }\end{array}$ & $\begin{array}{l}\text { - energy reduction through 'green } \\
\text { insulation'; } \\
\text { - heat island effect mitigation } \\
\text { through landscaping and } \\
\text { miniature raingardens. }\end{array}$ \\
\hline $\begin{array}{l}\text { Storm water } \\
\text { management }\end{array}$ & $\begin{array}{l}\text { - retention in underground } \\
\text { cisterns; } \\
\text { - Infiltration via permeable } \\
\text { surfaces } \\
\text { - purification using bio-filters } \\
\text { (plants); } \\
\text { - recycling via green wall and roof } \\
\text { systems; } \\
\text { - bio-filtration through daylighted } \\
\text { stream. }\end{array}$ & $\begin{array}{l}\text { - retention in underground } \\
\text { cisterns; } \\
\text { - Infiltration via permeable } \\
\text { surfaces; } \\
\text { - retention and bio-filtration } \\
\text { through swales, raingardens; } \\
\text { - purification using bio-filters } \\
\text { (plants); } \\
\text { - recycling via green wall and roof } \\
\text { systems; } \\
\text { - bio-filtration through daylighted } \\
\text { stream. }\end{array}$ & $\begin{array}{l}\text { - Infiltration via } \\
\text { permeable surfaces; } \\
\text { - retention and bio- } \\
\text { filtration through } \\
\text { stormwater planters } \\
\text { and raingardens; } \\
\text { - purification using bio- } \\
\text { filters (plants); } \\
\text { - recycling via green } \\
\text { wall and roof systems. }\end{array}$ & $\begin{array}{l}\text { - Infiltration via permeable } \\
\text { surfaces; } \\
\text { - retention and bio-filtration } \\
\text { through raingardens; } \\
\text { - recycling via green wall systems. }\end{array}$ \\
\hline $\begin{array}{l}\text { Biodiversity } \\
\text { management }\end{array}$ & $\begin{array}{l}\text { - green walls, roof and living } \\
\text { stream designed for biodiversity } \\
\text { enhancement and ecological } \\
\text { restoration; } \\
\text { - daylighted and restored stream } \\
\text { with riparian plants provide } \\
\text { habitats for wildlife and facilitate } \\
\text { species migration. }\end{array}$ & $\begin{array}{l}\text { - green walls designed for } \\
\text { biodiversity enhancement and } \\
\text { ecological restoration; } \\
\text { - daylighted and restored stream } \\
\text { with riparian plants provide } \\
\text { habitats for wildlife and facilitate } \\
\text { species migration. }\end{array}$ & $\begin{array}{l}\text { - green walls designed } \\
\text { for biodiversity } \\
\text { enhancement and } \\
\text { ecological restoration; } \\
\text { - use of native species } \\
\text { - green corridors } \\
\text { connect fragmented } \\
\text { green areas; } \\
\text { - raingardens provide } \\
\text { habitat for wildlife. }\end{array}$ & $\begin{array}{l}\text { - green walls, planters, miniature } \\
\text { raingardens designed for } \\
\text { biodiversity enhancement and } \\
\text { ecological restoration; } \\
\text { - habitats for wildlife and facilitate } \\
\text { species migration. }\end{array}$ \\
\hline $\begin{array}{l}\text { Street } \\
\text { furniture }\end{array}$ & $\begin{array}{l}\text { - integrated street furniture; tree } \\
\text { pits and sittings expressing } \\
\text { ecological sensitivity; }\end{array}$ & $\begin{array}{l}\text { - parklets in parking spaces; } \\
\text { - natural buffer between sidewalks } \\
\text { and traffic; } \\
\text { - public art supporting } \\
\text { environmental awareness; } \\
\text { - permeable paving facilitating } \\
\text { rainwater infiltration. }\end{array}$ & $\begin{array}{l}\text { - green wall and roof } \\
\text { systems; } \\
\text { - permeable paving } \\
\text { facilitating rainwater } \\
\text { infiltration. }\end{array}$ & $\begin{array}{l}\text { - planter-boxes with irrigation } \\
\text { systems; } \\
\text { - green wall system hanging } \\
\text { baskets and miniature } \\
\text { raingardens; } \\
\text { - permeable paving facilitating } \\
\text { rainwater infiltration. }\end{array}$ \\
\hline $\begin{array}{l}\text { Activity and } \\
\text { education }\end{array}$ & $\begin{array}{l}\text { - activity features for kids: } \\
\text { sculptures, water features; } \\
\text { - informative design of green walls } \\
\text { and roofs; } \\
\text { - interpretive plates and signs; } \\
\text { - exposed ecological systems. }\end{array}$ & $\begin{array}{l}\text { - interactive play equipment; } \\
\text { - interpretive plates and signs; } \\
\text { - exposed ecological systems; } \\
\text { - parklets and temporary } \\
\text { installations. }\end{array}$ & $\begin{array}{l}\text { - interpretive plates and } \\
\text { signs; } \\
\text { - exposed ecological } \\
\text { systems; } \\
\text { - green infrastructure } \\
\text { serves educational and } \\
\text { research purposes; } \\
\text { - activation of } \\
\text { shopfronts supports } \\
\text { community living. }\end{array}$ & $\begin{array}{l}\text { - green infrastructure serves } \\
\text { educational and research } \\
\text { purposes. }\end{array}$ \\
\hline
\end{tabular}

aspiration was to establish public green open spaces for residents of different ages and abilities. To meet the objectives, the city established the design criteria, which required all the design features to be used consistently along the nominated streets reflecting traditional character compatible with Downtown historic assets. As a result, all place-making amenities, including public art, were expected to provide a sense 


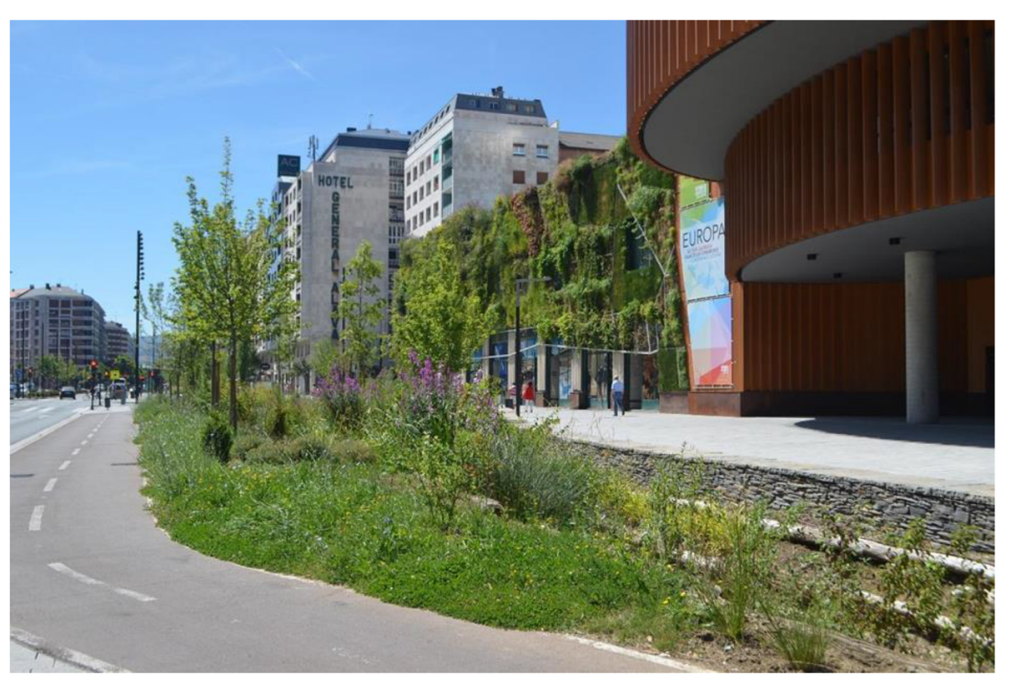

Fig. 1 Living stream opposite the Palace of Europe in Vitoria-Gasteiz, Spain. Source: Agata Cabanek

of place and evoke local heritage values as well as exhibiting biophilic features.

The biophilic elements included temporary planted installations, such as parklets in parking spaces, to improve and promote pedestrian-oriented activities rather than car use. Parklets help to raise awareness of local nature if their ecological design underpins the concept. Their presence may also lead to the reconsideration of the public realm; parklets could become permanent features evoking a biophilic sense of place.

To achieve the walkable city standards, the city council considered improvements supporting car-free living. One of the solutions was to provide more accessible transit options. To make streets more inviting and attractive, the traffic lane widths were reduced, the sidewalks were widened and bicycle lanes were introduced. The biophilic element was to provide extra space for landscaping buffers between pedestrians and traffic.

Bio-retention swales and rain gardens with riparian landscaping were used in some streets to treat rainwater run-off, thereby improving watershed conditions. The program also included daylighting of Strawberry Creek between Shattuck Square and BART Plaza. Daylighting the creek provided another opportunity to educate the residents about the ecological and biophilic values of natural waterbodies in the urban environment.

Living walls and roofs installed on the buildings bordering the streets provided green infrastructure services and served as aesthetic features enhancing the image of Downtown as an eco-destination. Accessible educational and recreational features in the form of interpretive plates, boards and interactive play equipment were included to educate people about natural systems and their ecological and economic values.
The local government initiated the Downtown revitalisation project which aimed at creating an Art and Theatre District. The funds to finance the public art projects came from many sources - certificates of participation, bond funds, capital, and federal transportation funds. Additionally, the town representatives were also able to secure private funds by consulting the local property and business owners. The money raised to be invested in public art was partially used to revitalise the local streets. Another important source of funding came from the earthquake retrofit bond launched in 1996, which added $\$ 4$ million for enhancing the streetscapes. As a result, the revitalisation of the Downtown project delivered many biophilic elements to the streets and created attractive, walkable restorative public spaces [81].

\section{SW Montgomery street in Portland, United States}

In 2004, Portland City Council approved the Green Street Policy Goals program through which they committed to promote and incorporate the use of green street facilities in public and private development. One of the first streets to undergo green transformation was SW Montgomery Street. The changes demonstrated an emerging new urban street design approach. This multisectional revitalisation project incorporated strategically designed green infrastructure and public transportation. SW Montgomery Street is considered to be Portland's boldest and most innovative green street project and has received national and international recognition [82]. The main planning strategy was to activate the neighbourhood, build community culture, enhance the pedestrian experience and showcase the sustainability agenda in the downtown area of the city. The concept applied, which included substantial biophilic street elements, was to become a new place-making model for other downtown 


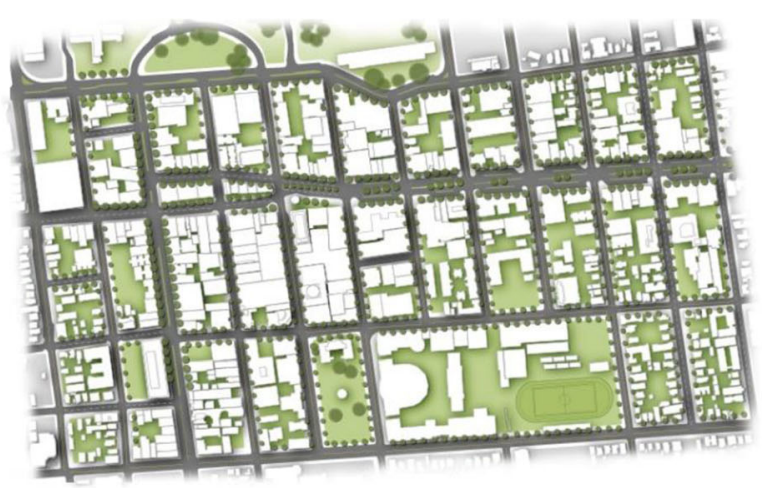

Source: cityofberkeley.info

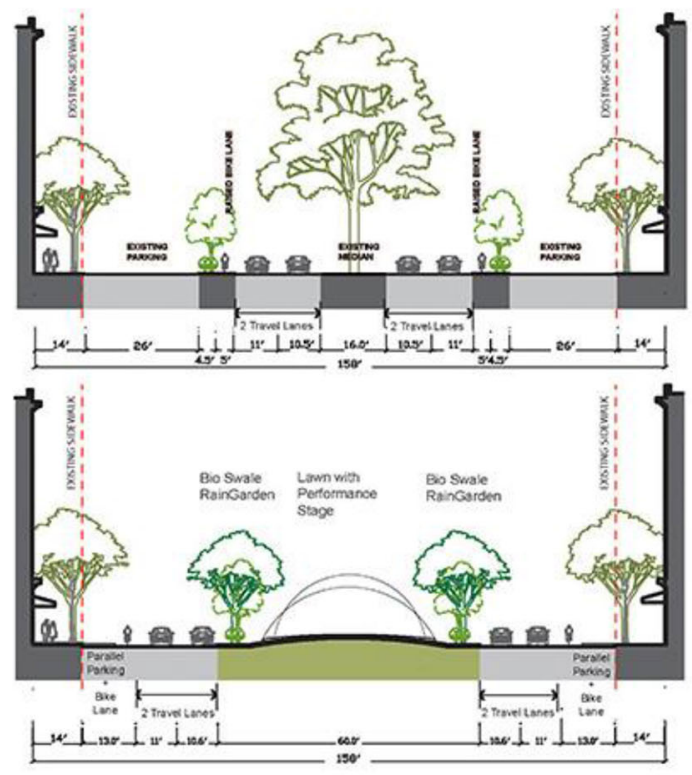

Source: Taecker Planning and Design

Fig. 2 SOSIP masterplan and section of street design integrating greeneries and multiple functions

streetscape projects in Portland. Street design goals included creating a pedestrian-oriented streetscape that incorporated a variety of green infrastructure solutions such as stormwater planters and swales (Fig. 3), green walls and roofs, and kerbless street design to offer a variety of sensory experiences throughout the seasons.

The biophilic street concept exemplified by SW Montgomery Street, emphasised pedestrian and bicycle travel over vehicular access. Bicycle and pedestrian safety became a priority, and in order to achieve it travel lanes were narrowed, some blocks were closed to through traffic and speed limits were lowered. The biophilic features could then be added to a kerb-less street with merged sidewalks that incorporated planting and swales to absorb stormwater [83].

Stormwater planters and swales also became educational amenities for the local communities. Since SW Montgomery Green Street runs through the Portland State
University campus, students are encouraged to take part in monitoring the performance of the green infrastructure. To facilitate the involvement of local citizens, public education about the corridor was incorporated into the design in the form of interpretive signage.

The project also proposed the installation of green walls and roofs on new development buildings. Stormwater from new building facades was directed into the stormwater planters to demonstrate innovative ways of stormwater management.

This project demonstrates how a busy urban street can be re-designed to improve ecological conditions, foster environmental learning, support community identity and neighbourhood engagement and maintain healthy business districts. The street delivers spaces for public interaction and serves as a transportation corridor whilst achieving much more because of its biophilic elements [84]. 


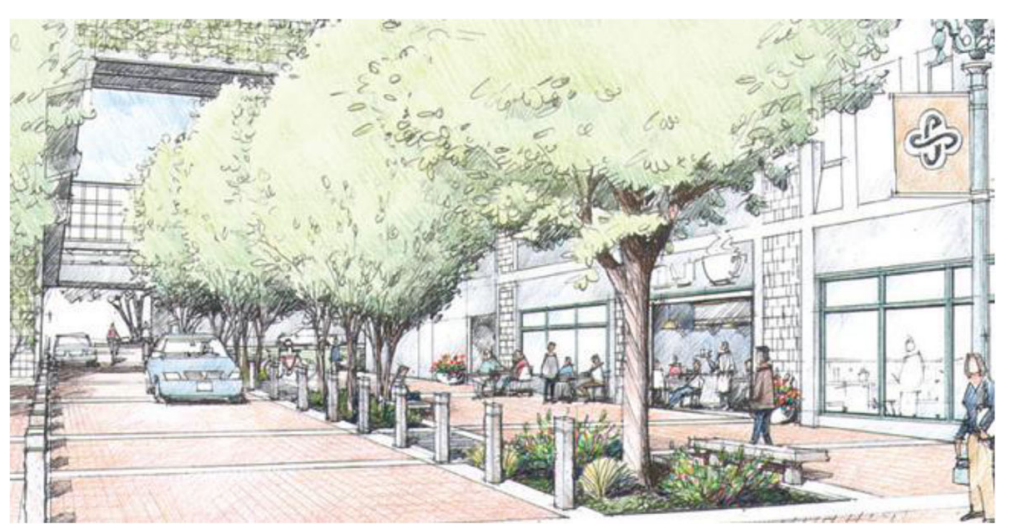

Fig. 3 SW Montgomery Street. Shared space with stormwater swales. Source: Nevue Ngan Associates

\section{Green lanes in Melbourne, Australia}

The rejuvenation and revival programs of lanes and alleys have emerged in many cities such as Austin, Chicago, Montreal, San Francisco, Sydney and Melbourne. Although the programs differ in objectives, there is an increasing use of biophilic elements that enable multiple extra objectives through ecosystem services, aesthetics and social life. The example chosen to illustrate this is from Melbourne.

In 2015, City of Melbourne established the Green Your Laneway program to encourage the transformation of Coromandel Place, Guildford Lane, Katherine Place and Meyers Place (Fig. 4) as replicable exemplars [85, 86]. As a part of the program, an interactive map was developed to mark the preselected laneways with strong potential for green transformation based on their local micro-climatic conditions and physical qualities. The program involved strong community engagement to ensure later community ownership of the transformed lanes.

Four lane typologies were selected: vertical gardens, forest lanes, park lanes and farm lanes. In this program, greening mainly meant planting tough ornamentals and establishing vegetable gardens to be cultivated by local residents. Elements such as window boxes, planter boxes with climbers, hanging baskets and miniature rain gardens were proposed (Fig. 5). The more spatially-demanding biophilic design elements involving water were not considered in the narrow laneways due to site constraints.

The planting strategies were designed to improve biodiversity, provide habitat for wildlife, filter pollution from the air and divert some stormwater run-off despite the small size of the gardens due to the restricted space.

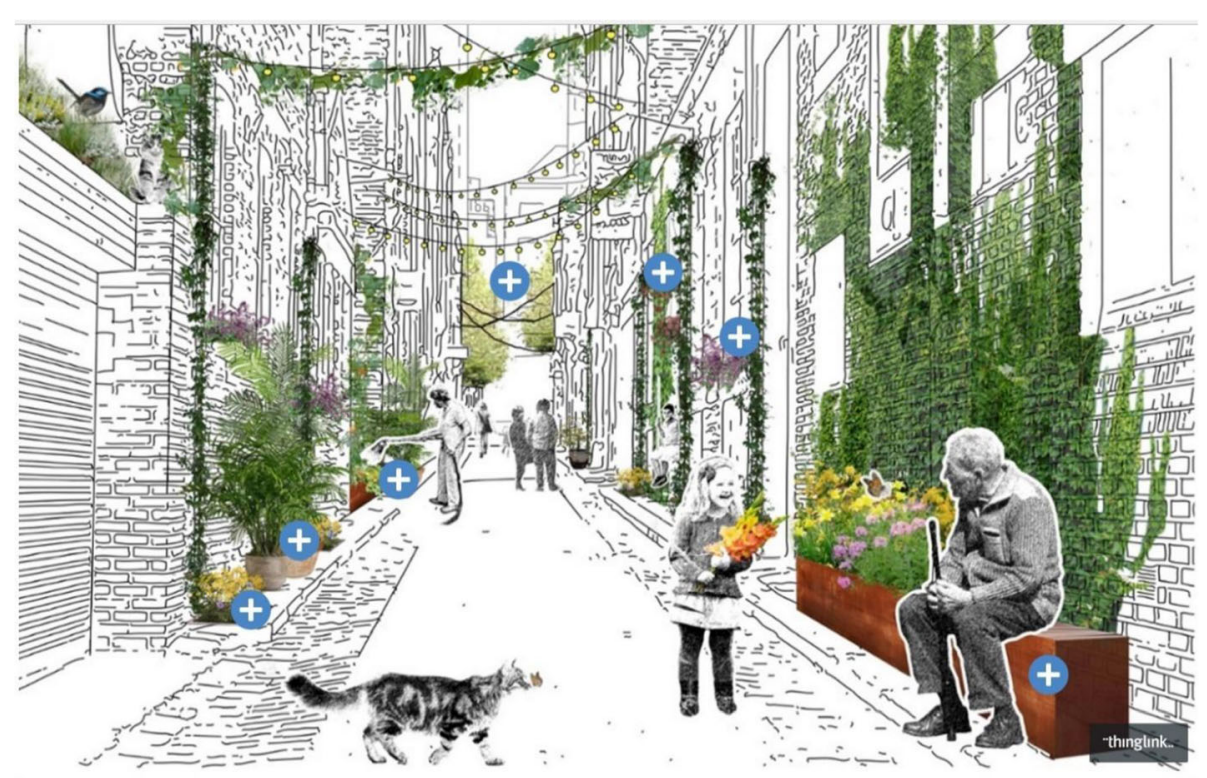

Fig. 4 Meyers Place in Melbourne. Source: https://participate.melbourne.vic.gov.au/greenlaneways 


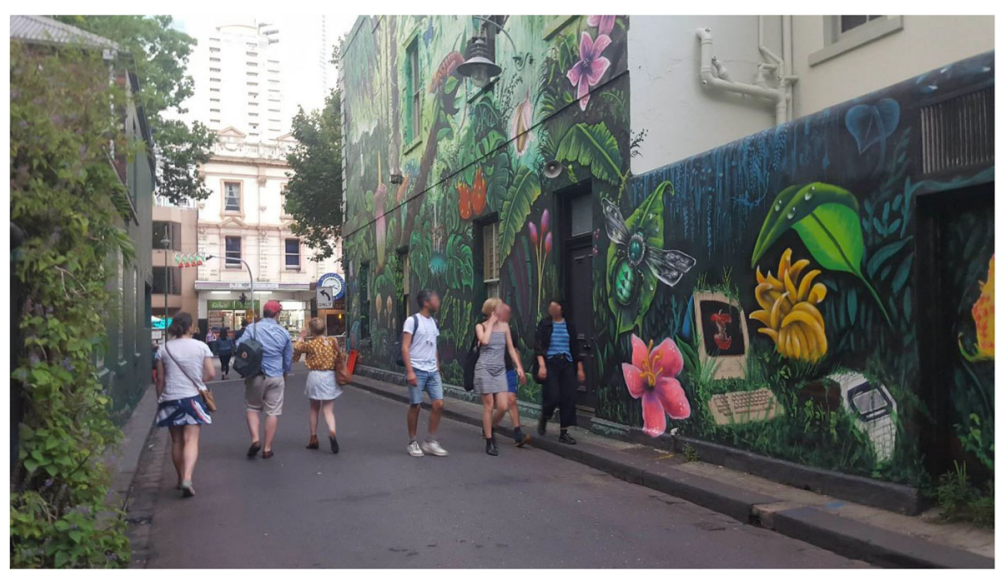

Fig. 5 Design concept for Guilford Lane in Melbourne. Source: Source: Agata Cabanek

Other environmental benefits, such as a reduction of carbon emissions and mitigation of urban heat island effect through 'green insulation', are also expected.

A range of social and economic benefits were projected by the council. The vision for the revitalisation of the lanes was to transform them from waste areas to useable public spaces. The lanes were rejuvenated to provide pleasant walkways and encourage people to spend time outdoors and engage in social activities. The Biophilic Streets Design Framework was almost completely implemented in terms of biophilic design elements, showing how much can be achieved in urban regeneration if these are central considerations in street rejuvenation or retrofit.

Several economic benefits are expected due to the activation of the lanes: increase in property values, increase in useable green outdoor spaces, extended life-span of permeable surfaces and savings on heating and cooling [87].

All four analysed examples of a street revitalisation project show multiple urban benefits which are summarised in Fig. 6. The many additional outcomes that surpass the usual functions of streets are evident.

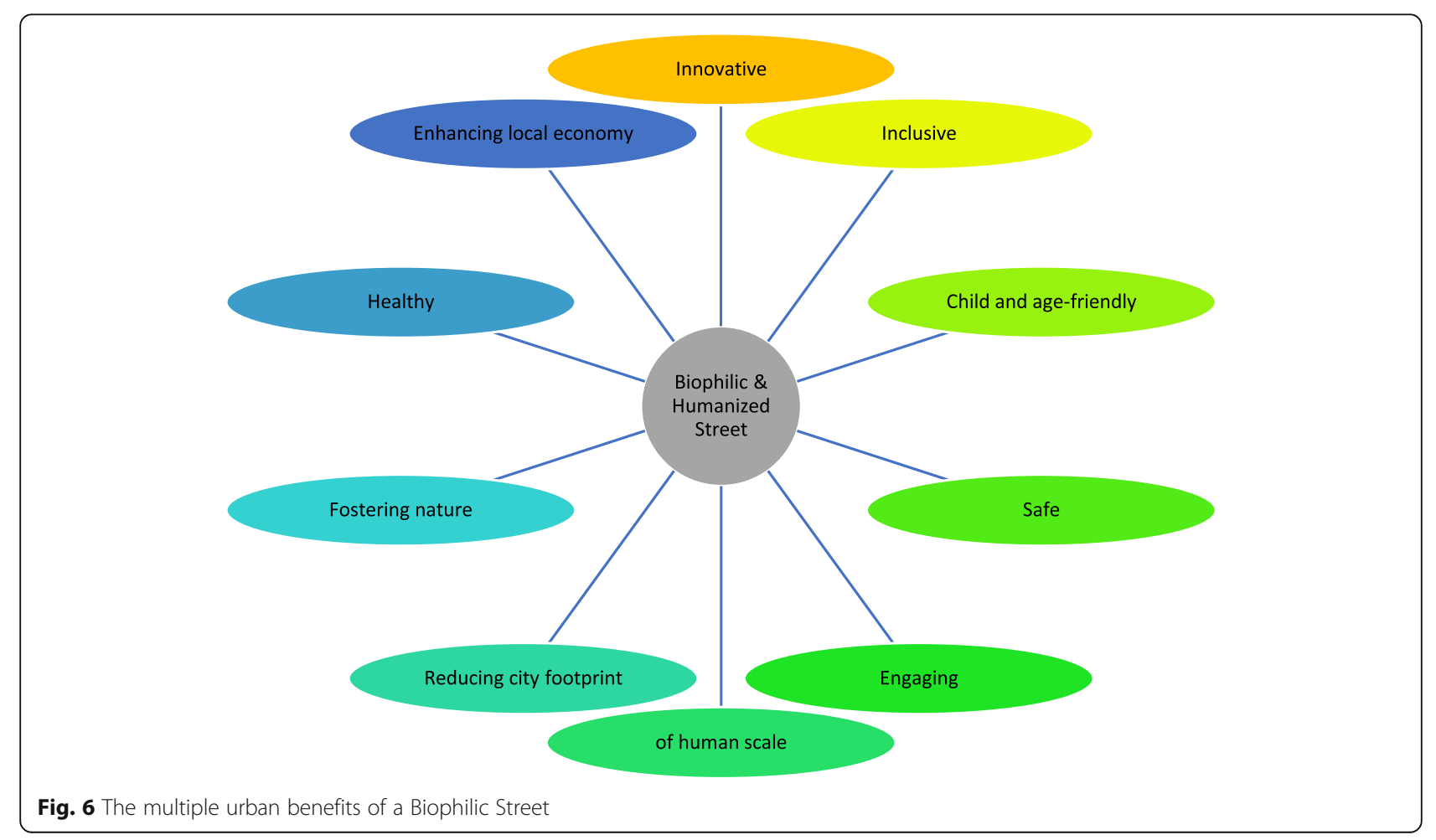


Cities would derive substantial value from considering biophilic enhancements in their streets as part of their future plans.

\section{Conclusions}

The Design Framework for Biophilic Streets, developed through this research, suggests that much more can be achieved within a city if streets are given biophilic design elements absent in traditional streets. Much can be achieved by adding the biophilic elements of green walls, green roofs and green balconies to building envelopes. Considerable benefit is also possible by adding elements to existing urban streets and road reserves: tree pits, street trees, linear gardens, pocket parks, bioswales, rain gardens, daylighting streams, and biophilic elements integrated with street furniture. The value of all of these biophilic features can be enhanced by incorporating educational and activity functions that can be seen and experienced in the street.

The four analysed street examples demonstrate how biophilic streets can be built in different climates, types of cities, urban structures, and levels of development. In the four analysed projects, the streets illustrated most of the biophilic elements in the Framework, though spatial limitations in high density urban fabrics do limit most of the water-oriented biophilic design elements. However, the majority of the examples were in medium density areas and were able to demonstrate that biophilic design elements can be incorporated into streets and create significant value outcomes in a multiplicity of economic, social and environmental ways. The value in humanising streets has been well established and it should now be possible to add the design dimensions of biophilic streets, as set out in the Biophilic Streets Design Framework. This is likely to enable a broader perspective on the value of streets in cities.

The Biophilic Streets Design Framework could be used by policy-makers and designers to move from the theoretical and imaginative biophilic urbanism discourse to reallife projects and urban interventions. When applied in conjunction with other design strategies and policies, for example, water-sensitive, biodiversity-sensitive, regenerative, resilient or ecological urban design, the Framework could help to improve urban infrastructure so it delivers restorative and health-promoting outcomes across any city.

Biophilic urbanism is becoming a major policy area for delivering tangible benefits to cities and their populations. This paper has suggested that by transforming urban streets into biophilic streets it is possible to add an extra dimension to biophilic urbanism. The biophilic street concept integrates the ideas advocated by Jane Jacobs and Jan Gehl who have demonstrated that peopleoriented streets contribute to a community's economic and social enhancement by integrating environmental approaches into the functional design of streets.
Future research is needed to monitor and quantify the performance of biophilic streets in addressing the adverse effects of climate change, environmental degradation and biodiversity loss; as well as how it can be cost-effective.

\section{Acknowledgements}

Not applicable.

\section{Authors' contributions}

Conceptualisation, AC; Methodology, AC,PN; Investigation, AC; Analysis AC, MZB; Original draft preparation, AC; Review \& Editing PN, AC, MZB. All authors read and approved the final manuscript.

\section{Funding}

This research funded by the CRC for Low Carbon Living Ltd. supported by the Cooperative Research Centres program, an Australian Government initiative.

\section{Availability of data and materials}

The dataset used and analysed during the current study are available from the corresponding author on reasonable request.

Ethics approval and consent to participate

Not applicable.

\section{Consent for publication}

Not applicable.

\section{Competing interests}

The authors declare they have no competing interests.

Received: 9 October 2019 Accepted: 7 May 2020

Published online: 08 July 2020

\section{References}

1. Kostof S. The city shaped: urban patterns and meanings through history. London: Thames and Hudson; 1999.

2. Mumford L. The city in history: its origins, its transformations, and its prospects. New York: Harcourt, Brace \& World; 1961.

3. Jacobs J. The death and life of great American cities. New York: Vintage; 1961.

4. Matan A, Newman P. People cities: the life and legacy of Jan Gehl. Washington DC: Island Press; 2016.

5. Gehl J. Cities for people. Washington DC: Island Press; 2010

6. Kellert SR, Heerwagen J, Mador M. Biophilic design: the theory, science, and practice of bringing buildings to life. Hoboken: Wiley; 2008.

7. Beatley T. Biophilic cities: integrating nature into urban design and planning. Washington, DC: Island Press; 2010.

8. Beatley T. Handbook of biophilic design. Washington, DC: Island Press; 2016.

9. Wilson EO. Biophilia. Cambridge: Harvard University Press; 1984.

10. Kellert S, Calabrese E. The practice of biophilic design. 2015. www.biophilicdesign.com. Accessed 16 Sept 2019.

11. Kellert S, Finnegan B. Biophilic design: the architecture of life. A 60-minute video. 2011. www.bullfrogfilms.com. Accessed 17 Sept 2019.

12. Salingaros NA. Biophilia and healing environments: healthy principles for designing the built world. New York: Terrapin Bright Green LLC; 2015.

13. Newman P. Biophilic urbanism: a case study on Singapore. Aust Plann. 2014 51:47-65.

14. Newman P, Beatley T, Boyer H. Resilient cities: overcoming automobile dependence. Washington DC: Island Press; 2017.

15. Newman P, Jennings I. Cities as sustainable ecosystems. Washington DC: Island Press; 2008.

16. Urlich RS. View through a window may influence recovery from surgery. Science. 1984:224:420-1.

17. Kaplan R, Kaplan S. The experience of nature: a psychological perspective. Cambridge: Cambridge University Press; 1989.

18. Terrapin Bright Green. Fourteen patterns of biophilic design. Improving health \& well-being in the built environment. 2012 http//www. terrapinbrightgreen.com/reports/14-patterns/. Accessed 10 Sept 2018. 
19. Yuchi W, Sbihi H, Davies H, Tamburic L, Brauer M. Road proximity, air pollution, noise, green space and neurologic disease incidence: a population-based cohort study. Environ Health. 2020;19(1):8.

20. Zelenski JM, Dopko RL, Capaldi CA. Cooperation is in our nature: nature exposure may promote cooperative and environmentally sustainable behaviour. J Environ Psychol. 2015;42:24-31.

21. Cameron J. Educating for place responsiveness: an Australian perspective on ethical practice. Ethics Place Environ. 2003;6:99-116.

22. Mang $P$, Reed B. Designing from place: a regenerative framework and methodology. Build Res Inf. 2011;40:23-8.

23. Steiner FR, Thompson GF, Carbonell A. Nature and cities. The ecological imperative in urban design and planning. Cambridge: Lincoln Institute of Land Policy; 2016

24. Hirt S, Zahm D. The urban wisdom of Jane Jacobs. Abingdon: Routledge; 2012.

25. Alexiou-Sparberg A. Jane Jacobs: urban visionary. New Brunswick: Rutgers University Press; 2006.

26. Jacobs J. The economy of cities. New York: Vintage Books; 1970

27. Leinberger CB. The option of urbanism. Washington, DC: Island Press; 2010.

28. Leinberger CB, Lynch P. Foot traffic ahead: ranking Walkable urbanism in America's largest metros. Washington, DC: George Washington University School of Business, Center for Real Estate and Urban Analysis; 2014.

29. Yigitcanlar T. Making space and place for the knowledge economy: knowledge-based development of Australian cities. Eur Plan Stud. 2010;11: $1769-86$.

30. Newman P, Kenworthy J. The end of mobile dependence. How cities are moving beyond car-based planning. Washington, DC: Island Press; 2015.

31. Gehl J. Life between buildings. Using public space. Washington DC: Island Press; 2011.

32. Gehl J, Kaefer L, Reigstad S. Close encounters with buildings. Urban Des Int. 2006;11:29-47.

33. Fu Y, Zhang X. Planning for sustainable cities? Comparative content analysis of the master plans of eco, low-carbon and conventional new towns in China. Habitat Int. 2017:63:55-66.

34. Zhang $X_{1}$ Li H. Urban resilience and urban sustainability: what we know and what we do not know? Cities. 2018;72:141-8.

35. NACTO. Global street design guide. Washington DC: Island Press; 2017

36. Girling C, Kellett R. Skinny streets and green neighbourhoods: design for environment and community. Washington DC: Island Press; 2005.

37. Diane Toomey. Designing for the urban landscape to meet $21 \mathrm{st}$ century challenges. 2012. http://e360.yale.edu/features/martha_schwartz_ urban_landscape_designs_to_meet_21st_century_challenges. Accessed 12 Aug 2018.

38. Burton E, Mitchell L. Inclusive urban design: streets for life. Oxford: Architectural Press; 2006.

39. Carmona M, Heath T, Oc T, Tiesdell T. Public places urban spaces. Oxford: Taylor \& Francis Ltd; 2010.

40. Newman P, Kenworthy J. Sustainability and cities. Washington DC: Island Press; 1999.

41. Course D. Traffic calming: a social issue. Bull Sci Technol Soc. 2004;24:138-44.

42. Grana A, Guerrieri M. Exploring effects of area-wide traffic calming measures on urban road sustainable safety. J Sustain Dev. 2010;3:38.

43. Traffic calming 101. 2008. https://www.pps.org/reference/livememtraffic/ \#CHICANES. Accessed 17 Sept 2019.

44. Wong NH, Chen Y. The role of urban greenery in high-density cities. In: Ng E, editor. Designing high-density cities for social \& environmental sustainability. Routledge; Abingdon 2010. p. 227-262.

45. Ng E, Chen L, Wang Y, Yuan C. A study on the cooling effects of greening in a high-density city: an experience from Hong Kong. Build Environ. 2012 47:256-71.

46. Chiesura A. The role of urban parks for the sustainable city. Landsc Urban Plan. 2004;68:129-38.

47. Bowler D, Buyung-Ali L, Knight TM, Pullin AS. Urban greening to cool towns and cities: a systematic review of the empirical evidence. Landsc Urban Plan. 2010;97:147-55

48. Norton B, Coutts A, Livesley S, Harris R, Hunter A, Williams N. Planning for cooler cities: a framework to prioritise green infrastructure to mitigate high temperatures in urban landscapes. Landsc Urban Plan. 2015;134:127-38.

49. Loughner C, Allen D, Zhang D, Pickering K, Dickerson R, Landry L. Roles of urban tree canopy and buildings in urban Heat Island effect:
Parametrization and preliminary results. J Appl Meteorol Climatol. 2012;51: 1775-93.

50. Souch CA, Souch C. The effects of threes on summertime below canopy urban climates: a case study Bloomington, Indiana. J Arboric. 1993;19:303-12.

51. Alexandri $E$, Jones $P$. Temperature decreases in an urban canyon due to green walls and green roofs in diverse climates. Build Environ. 2008;43: 480-93.

52. Getter K, Rowe B. The role of extensive green roofs in sustainable development. HortScience. 2006;41:1276-85.

53. Kew B, Pennypacker E, Echols S. Can green walls contribute to Stormwater management? A study of cistern storage green wall first flush capture. J Green Build. 2014;9:85-99.

54. Dietz ME. Low impact development practices: a review of current research and recommendations for future directions. Water Air Soil Pollut. 2007;186: 351-63.

55. Stovin V, Vesuvian G, De-Ville S. Defining green roof detention performance. Urban Water J. 2017;14:574-88.

56. Weinmaster M. Are green walls as 'green' as they look? An introduction to the various technologies and ecological benefits of green walls. J Green Build. 2009;4:3-18.

57. Alvery AA. Promoting and preserving biodiversity in the urban forest. Urban For Urban Green. 2006;5:195-201.

58. Oprea M, Mendes P, Vieira T, Ditchfield A. Do wooded streets provide connectivity for bats in an urban landscape? Biodivers Conserv. 2009;18: 2361-71.

59. Threlfall CG, Mata L, Mackie JA, Hahs AK, Stork NE, Williams NSG, Livesley SJ. Increasing biodiversity in urban green spaces through simple vegetation interventions. J Appl Ecol. 2017;54:1874-83.

60. Katti M. Biodiversity can flourish on an urban planet. 2014. http:// theconversation.com/biodiversity-can-flourish-on-an-urban-planet-18723. Accessed 16 Sept 2019.

61. Angold P, Sadler J, Hill M, Pulin A, Rushton S. Biodiversity in urban habitat patches. Sci Total Environ. 2006:360:196-204.

62. Francis $\mathrm{R}$, Lorimer J. Urban reconciliation ecology: the potential of living roofs and walls. J Environ Manag. 2011. https://doi.org/10.1016/j.jenvman. 2011.01.012.

63. Collins R, Schaafsmab M, Hudsona MD. The value of green walls to urban biodiversity. Land Use Policy. 2017;64:114-23.

64. Williams NSG, Lundholm J, Maclvor JS. FORUM: do green roofs help urban biodiversity conservation? J Appl Ecol. 2014;51:1469-759.

65. Chiquet C, Dover JV, Mitchell P. Birds and the urban environment: the value of green walls. Urban Ecosyst. 2013;16:453-62.

66. Dahlenburg J, Birtles P. All roads lead to WSUD: exploring the biodiversity, human health and social benefits of WSUD. Barton: Engineers Australia; 2012. p. 94.

67. Kazemi F, Beecham S, Gibbs J. Streetscape biodiversity and the role of bioretention swales in an Australian urban environment. Landsc Urban Plan. 2022;101:139-48.

68. Williams DB. Seattle walks: discovering history and nature in the city. Washington, DC: University of Washington Press; 2017.

69. Shueh J. Startup invents a bench that can cut air pollution by up to 30 percent. 2016. http://www.govtech.com/products/Startup-Invents-BenchReduces-Air-Pollution.html. Accessed 16 Sept 2018.

70. Pultarova T. Built environment - pollution: inspired ideas for purer air. Eng Technol. 2017;12(4):46-7. https://doi.org/10.1049/et.2017.0425. Accessed 16 Sept 2019.

71. Gallas T, McKennan P. The living bus shelter (Report No. 37). 2016. https:// www.mplsdowntown.com/wp-content/uploads/2017/03/37 TheLivingBusShelter_FinalReport.pdf. Accessed 15 May 2019.

72. Yuka Yoneda. Philadelphia plants its very first bus stop green roof! 2011 https://inhabitat.com/philadelphia-plants-its-very-first-bus-stop-green-roof/ \#ixzz2IZueshlB. Accessed 10 May 2019.

73. WVTTK Architects. Living bus shelter in eindhoven is overflowing with plants. 2012. https://inhabitat.com/wvttk-architects-living-bus-shelter-ineindhoven-is-overflowing-with-plants/ Accessed 10 May 2019.

74. A street you go to, not just through: principles for fostering streets as places. 2015. https://www.pps.org/reference/8-principles-streets-as-places/. Accessed 18 Sept 2019.

75. The environment protection authority in South Australia. Rain garden program wraps up. 2018. https://www.epa.sa.gov.au/articles/20201518/11/2 8/rain_garden_program_wraps_up. Accessed 17 Sept 2019. 
76. City of Portland. Green street steward program. https://www. portlandoregon.gov/bes/52501. Accessed 25 Jan 2020.

77. Soares A, Rego F, Mcpherson E, Simpson J, Peper P, Xiao Q. Benefits and costs of street trees in Lisbon, Portugal. Urban Forestry Urban Green. 2011; 10:69-78.

78. Donovan G, Butry D. Trees in the city: valuing street trees in Portland, Oregon. Landsc Urban Plan. 2010;94(2):77-83.

79. Ayuntamiento de Vitoria-Gasteiz. Anuario estadístico. 2011. https://www. vitoria-gasteiz.org/wb021/was/contenidoAction.do?idioma=es\&uid=_7d232 eb4_11e86578bd6_7feb. Accessed 14 Jan 2020.

80. City of Berkeley. Downtown streets \& open space improvement plan. 2012 https://www.cityofberkeley.info/ContentDisplay.aspx?d=47724. Accessed 10 Jan 2018.

81. Kemp RL. Community renewal through municipal investment, a handbook for citizens and public officials. Jefferson: McFafland \& Company; 2015.

82. American Society of Landscape Architects. SW Montgomery Street: connecting the West Hills to Willamette River. 2012. https://www.asla.org/2 012awards/572.html. Accessed 17 Sept 2019.

83. Nevue Ngan Associates. SW Montgomery Street: connecting the West Hills to Willamette River. 2009. https://www.pdx.edu/campus-planning/sites/ www.pdx.edu.campus-planning/files/2009_MontgomeryGreenStreet_Plan\%2 0\%281\%29.pdf. Accessed 10 Sept 2019.

84. Rottle N, Yocom K. Basics landscape architecture 02: ecological design. Lausanne: AVA Publishing SA; 2010

85. Melbourne's first green laneway unveiled. Construction Engineering Australia, 2017;5(3):23. https://search.informit.com.au/documentSummary; $\mathrm{dn}=249264647527662 ; \mathrm{res}=\mid$ ELENG. ISSN: 2204-7247. Accessed 17 Sept 2019.

86. City of Melbourne. Laneway visions. Greening map and laneway concepts. https://participate.melbourne.vic.gov.au/greenlaneways/laneway-visions. Accessed 17 Sept 2019.

87. City of Melbourne. Greening laneways. https://www.melbourne.vic.gov.au/ community/greening-the-city/green-infrastructure/pages/greeninglaneways.aspx. Accessed 17 Sept 2019.

\section{Publisher's Note}

Springer Nature remains neutral with regard to jurisdictional claims in published maps and institutional affiliations.

Ready to submit your research? Choose BMC and benefit from:

- fast, convenient online submission

- thorough peer review by experienced researchers in your field

- rapid publication on acceptance

- support for research data, including large and complex data types

- gold Open Access which fosters wider collaboration and increased citations

- maximum visibility for your research: over $100 \mathrm{M}$ website views per year

At $\mathrm{BMC}$, research is always in progress.

Learn more biomedcentral.com/submissions 